\title{
PENERAPAN SOFTWARE GEOGEBRA UNTUK MENINGKATKAN KEMAMPUAN KOMUNIKASI MATEMATIS DAN KEAKTIFAN SISWA KELAS VIII SMP
}

\author{
Berry Bernandus Sembiring \\ Universitas Katolik Santo Thomas, Medan; \\ berrysembiring11@gmail.com
}

\begin{abstract}
Abstrak. Penelitian ini bertujuan untuk mengetahui apakah pembelajaran dengan model TPS (Think Pair Share) berbantuan Software Geogebra dapat meningkatkan kemampuan komunikasi matematis dan keaktivan siswa pada pembelajaran matematika dengan materi kubus dan balok kelas VIII SMP Dharma Wanita Pertiwi. Metode penelitian ini adalah Penelitian Tindakan Kelas (PTK) yang dilakukan di kelas VIII SMP Dharma Wanita Pertiwi. Hasil temuan peneliti ini menunjukkan: (1) siswa yang sudah mencapai Kriteria Ketuntasan Minimum (KKM) yaitu 75, diantaranya 17 orang (56,67\%) sedangkan yang belum mencapai KKM adalah 13 orang (43,33\%). Nilai ratarata hasil tes kemampuan komunikasi matematis siswa komunikasi matematis siswa pada siklus I mencapai 66,87. jumlah siswa yang tuntas secara klasikal belum mencapai 75\%, maka dilanjutkan pada siklus II. Siswa yang sudah mencapai Kriteria Ketuntasan Minimum (KKM) adalah 25 orang (83,33\%) dan siswa yang belum mencapai $\mathrm{kkm}$ adalah 5 orang (16,66\%). Nilai rata-rata tes kemampuan komunikasi matematis siswa siklus II mencapai 82,5. (2) Pembelajaran dengan berbantuan Software Geogebra dan model pembelajaran (Think Pair Share)TPS berlangsung dengan baik dan efektif untuk dilakukan terlihat dari lembar observasi aktivitas guru dan lembar angket keaktifan siswa . aktivitas guru pada siklus I, dengan rata-rata 75\% dan masih kriteria baik, maka dilakukan tindakan selanjutnya untuk siklus II dan hasil lembar aktivitas guru siklus II dengan rata-rata 90\%, dan angket keaktifan siswa siklus I ratarata $62,26 \%$ dan meningkat pada siklus II menjadi $71,53 \%$. Hal ini menunjukkan bahwa penggunaan Software Geogebra dapat digunakan untuk meningkatkan kemampuan komunikasi matematis dan keaktifan siswa kelas VIII pada materi kubus dan balok.
\end{abstract}

Kata Kunci. Think Pair Share, komunikasi matematis, keaktifan.

Abstract. This study aims to determine whether learning with the TPS (Think Pair Share) model assisted by Geogebra Software can improve students' mathematical communication skills and activeness in learning mathematics

Cartesius: Jurnal Pendidikan Matematika Vol. 3, No. 1

CProdi Pendidikan Matematika Universitas Katolik Santo Thomas 
with cube and block material in class VIII of Dharma Wanita Pertiwi Middle School. This research method is Classroom Action Research (CAR) conducted in class VIII of the Dharma Wanita Pertiwi Middle School. The findings of this researcher show: (1) students who have reached the Minimum Completion Criteria (KKM) of 75, including 17 people (56.67\%) while those who have not reached the KKM are 13 people (43.33\%). The average value of the test results of students' mathematical communication skills mathematical communication students in the first cycle reached 66.87. the number of students who finished classically has not reached $75 \%$, then continued in cycle II. Students who have reached the Minimum Completion Criteria (KKM) are 25 people (83.33\%) and students who have not reached $\mathrm{kkm}$ are 5 people (16.66\%). The average value of students' mathematical communication skills test cycle II reached 82.5. (2) Learning with the help of Geogebra Software and the TPS Think Think Share model takes place properly and effectively to be seen from the observation sheet of teacher activity and student activeness questionnaire sheets. the activities of teachers in the first cycle, with an average of $75 \%$ and still good criteria, then the next action is carried out for the second cycle and the results of the cycle II teacher activity sheet with an average of $90 \%$, and the active questionnaire for the first cycle students is $62.26 \%$ and increased in cycle II to $71.53 \%$. This shows that the use of Geogebra Software can be used to improve mathematical communication skills and activeness of VIII grade students on cube and beam material.

Keywords. Think Pair Share, mathematical communication, activeness.

\section{PENDAHULUAN}

Pendidikan mempunyai peranan penting dalam kehidupan sehari-hari. Pendidikan merupakan suatu kebutuhan pokok bagi setiap umat manusia, karena dengan adanya pendidikan manusia akan lebih percaya diri dan pendidikan juga bisa membantu manusia melihat jati dirinya. Seperti yang tertulis di UU NO 20 Tahun 2003 tentang sistem pendidikan, yaitu usaha seseorang untuk memperoleh pembelajaran, yang mana pada masa pembelajaran tersebut peserta didik diharapkan mampu mengembangkan potensi, mencarijati diri, dan juga memiliki keterampilan yang akan dipergunakan dan berguna bagi diri pribadi maupun orang lain.

Tujuan pendidikan adalah menempah dan mengembangkan suatu keterampilan dan kemempuan yang dimiliki akar kiranya peserta didik

Cartesius: Jurnal Pendidikan Matematika Vol. 3, No. 1

CProdi Pendidikan Matematika Universitas Katolik Santo Thomas 
tersebut mampu menjadi manusia yang berpendidikan dan bermartabat, serta menjadikannya lebih mandiri, kreatif, dan memiliki rasa bertanggung jawab. Salah satu pendidikan yang sangat penting bagi manusia adalah pendidikan matematika. Matematika perlu diajarkan karena matematika adalah sebuah ilmu dasar, dimana matematika itu sendiri merupakan ilmu yang sangat berperan penting dalam perkembangan teknologi, dan juga matematika merupakan ilmu yang akan banyak melakukan perubahanperubahan di zaman sekarang hingga zaman berikutnya.

Menghadapi perkembangan ilmu pengetahuan dan teknologi yang begitu pesat saat ini, diperlukan sumber daya manusia yang handal dan mampu berkompetisi secara global. Menurut (Amir 2014:18) menyatakan bahwa segala sesuatu yang terjadi dikehidupan ini adalah kompetisi, yang mana manusia akan bersaing dan juga memilih untuk mendapatkan hal yang terbaik dan berkualitas, oleh sebab itu perlunya kemampuan komunikasi dan juga keterampilan, karena dari kemampuan tersebut manusia mampu beradaptasi dan juga melahirkan teknologi serta sosial budaya antar sesama. Tujuan umum matematika menurut NCTM adalah 1) Kemampuan pemecahan masalah, 2) kemampuan penalaran, 3) kemampuan berkomunikasi, 4) kemampuan membuat koneksi, 5) kemampuan representasi. Hal lain juga dikatakan oleh kemendikbud 2013 (dalam Faudi 2016 : 46 ) menyatakan bahwa pembelajaran matematika mengutamakan pembelajaran yang menggunakan pendekakatan scientific (ilmiah), dalam pembelajaran matematika kegiatan yang dilakukan agar pemebelajaran bermakna yaitu mencipta, menanya, mencoba, menalar, menyaji, mengamati, dan juga berkomunikasi.

Dari dua pendapat diatas ada terdapat banyak kesamaan tentang tujuan mempelajari matematika yaitu tentang komunikasi siswa, hal ini sangat penting karena dengan komunikasi yang baik siswa akan lebih mudah dalam mengikuti pembelajaran matematika.

Amir (2014:20) menyatakan bahwa Kemampuan komunikasi matematis marupakan kesanggupan atau kecakapan soerang sisiwa untuk dapat

Cartesius: Jurnal Pendidikan Matematika Vol. 3, No. 1

CProdi Pendidikan Matematika Universitas Katolik Santo Thomas 
menyatakan dan menafsirkan gagasan metematika secara lisan, tertulis, atau mendemonstrasian apa yang ada dalam soal matematika. Kemampuan komunikasi matematis merupakan kemampuan siswa dalam menyampaikan ide-ide atau gagasan matematika yang telah dipelajarinya. Selain itu NCTM mengatakan bahwa komunikasi matematis mampu mempresentasikan suatu masalah kedalam bentuk matematika atau simbol matematika dan mampu menyampaikan suatu gagasan dan juga ide-ide baik secara lisan maupun tulisan, serta menyajikannya kedalam bentuk aljabar. NCTM juga menekankan komunikasi matematis pada kemampuan siswa dalam hal :1) mengatur dan mangkondisikan pemikiran-pemikiran matematis mereka melalui komunikasi, 2) mengkomunikasikan cara berpikir matematika kepada guru dan teman-teman secara merata dab juga bisa diterima dengan baik,3) mengevaluasi pemikiran matematis yang dipakai diterima oleh teman sendiri, 4) menggunakan kalimat dan bahasa yang baik dan sesuai dengan matematika dalam menyampaikan ide-ide. Sedangkan menurut Sumarno (2012:24) komunikasi matematis meliputi kemampuan siswa: 1) menghubungkan benda nyata ke dalam ide matematika, 2) mempresentasikan ide, dan relasi matematik secara lisan maupun tulisan dengan benda nyata, grafik dan aljabar, 3) menjelaskan peristiwa kontekstuan kedalam bentuk simbol dan aljabar matematika, 4) mendengarkan, berdiskusi tentang matematika, 5) membaca dengan pemahaman atau presentasi matematika tertulis, 6) membuat konjektur, menyusun argumen, merumuskan definisi dan generalisasi, 7) menjelaskan dan membuat pertanyaan tentang matematika yang telah dipelajari.

Komunikasi matematis juga akan berpengaruh pada keaktifan belajar siswa karena dengan dengan komunikasi matematis yang baik siswa akan lebik aktif dan juga lebih mudah dalam memahami pelajaran, dan berdiskusi dengan sesama siswa lain. Hal tersebut akan membuat suasana belajar dikelas menjadi menyenangkan. Seperti pada penelitian yang dilakukan oleh (Firdawati 241:2018) yang mana hasil penelitiannya menyimpulkan bahwa adanya hubungan antara keaktifan belajar siswa terhadap kemampuan komunikasi matematis. Diambil dari kesimpulan dapat dikatakan bahwa keaktivan itu sendiri memiliki keterkaitan dengan kemampuan komunikasi

Cartesius: Jurnal Pendidikan Matematika Vol. 3, No. 1

CProdi Pendidikan Matematika Universitas Katolik Santo Thomas 
matematis hal ini dapat dilihat dari hasil belajar siswa dimana jika siswa keaktivan pada saat belajarnya baik maka kemampuan komunikasinya pun juga akan berkembang baik. Hal yang sama juga dikatakan oleh (Ramlah, dkk., 2014) menyatakan bahwa keaktifan belajar memiliki pengaruh yang signifikan terhadap prestasi belajar. Dari pendapat diatas dapat disimpulkan bahwa keaktifan belajar siswa memiliki hubungan pada setiap kemampuan komunikasi matematis.

Hal serupa juga terjadi di SMP Dharma Wanita Pertiwi yang mana kemampuan komunikasi matematis di sekolah ini masih kurang, hal ini dapat dilihat dari nilai-nilai siswa yang masih banyak diantaranya siswa yang belum mencapai melewati nilai KKM. Guru yang mengajar di sekolah ini juga mengatakan pada saat pembelajaran banyak siswa yang kurang memperhatikan, dan keaktifan belajar siswa masih kurang. Dari hasil wawancara yang dilakukan kepada guru mata pelajaran matematika bapak Bukhori M.Pd. dipeoleh interaksi bahwa siswa mudah bosan dengan pengajaran yang dibawakan guru, dan juga siswa kurang aktif, kurang berani bertanya kepada guru ataupun meminta guru mengulangi penjelasan yang disampaikan guru tersebut. Metode yang diterapkan guru tersebut pun masih mengguanakan metode konvensional yang mana guru masih menjadi pusat pembelajaran hingga akhirnya siswa bosan dengan pengajaran yang digunakan guru. Hal tersebut terbukti pada saat saya memberikan soal minitest yang dilakukan di kelas VIII SMP Dharma Wanita Pertiwi yang menunjukkan bahwa siswa masih banyak yang kurang mapu melukiskan gambar, memberikan gagasan terhadap materi yang ada, belum paham tentang materi yang bersangkutan jika dikaitkan ke kehidupan sehari-hari, dan juga kurang paham dalam membuat gagasan dengan pemahaman sendiri dalam penyelesaian masalah matematika yang tepat. Berikut soal minitest kemampuan komunikasi matematis siswa yaitu:

1. Luis dan kawan-kawan berencana ingin membuat tiang gawang sepak bola. Satu tiang gawang terdiri dari 3 bambu yang di ikat menjadi satu. Jika diameter tiap bambu adalah $14 \mathrm{~cm}$, maka berapakah panjang tali maksimum yang dibutuhkan Luis untuk mengikat 3 bambu tersebut?

Cartesius: Jurnal Pendidikan Matematika Vol. 3, No. 1

CProdi Pendidikan Matematika Universitas Katolik Santo Thomas 

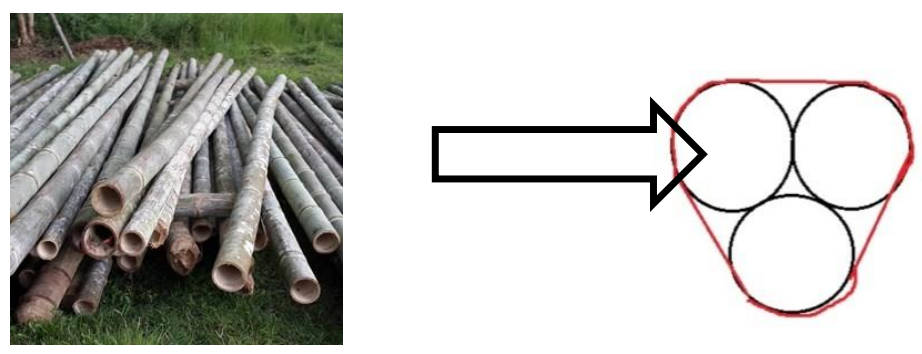

Gambar 1. Bambu dan Sketsa Ikatan Tiga Bambu

2. Jeani adalah seorang ahli mesin di suatu pabrik mesin. Suatu hari dia diberikan tugas dari kepala pabrik untuk membuatkan mesin terbaru, yang mana pada mesin tersebut terdapat dua rotator berbentuk lingkaran dengan jari-jari masing-masingnya $5 \mathrm{~m}$ dan $8 \mathrm{~m}$. Jika jarak antara pusat kedua rotator adalah $5 \mathrm{~m}$. Maka tentukanlah :

a. Gambar sketsa kedua rotator tersebut.

b. Jika harga 1 meter tali Rp 100.000 berapakah biaya yang perlu dibayar untuk menghubungkan kedua rotator tersebut.

3. Garis singgung lingkaran adalah garis yang memotong suatu lingkaran di satu titik dan berpotongan tegak lurus dengan jari-jari disuatu titik singgungnya. Coba jelaskan pengertian tersebut melalui suatu masalah yang berhubungan dengan objek, dan mengunakan bahasa kamu sendiri?

Dari hasil disimpulkan bahwa benar kalau komunikasi matematis siswa masih rendah. Hal ini juga berpengaruh pada kegiatan belajar mengajar dikelas yang mana pada saat pembelajaran siswa kurang aktif. Permasalahan-permasalahan tersebut tentunya tidak terlepas dari model pembelajaran yang dibawakan oleh guru.

Melihat dari begitu pentingnya matematika bagi kehidupan manusia, maka diharapkan para pendidik untuk lebih tepat dalam memilih model pembelajaran, agar suasana pada saat pembelajaran tidak terlalu membosankan melainkan nyaman dan juga dapat menumbuhkan keaktifan siswa dan juga kemampuan komunikasi siswa. Salah satu pembelaran yang bisa membantu meningkatkan kemampuan komunikasi matematis dan juga keaktifan siswa adalah pembelajaran menggunakan bantuan software

Cartesius: Jurnal Pendidikan Matematika Vol. 3, No. 1

CProdi Pendidikan Matematika Universitas Katolik Santo Thomas 
matematika, salah satu software matematika yang dapat digunakan adalah software Geogebra. Menurut Hohenwarter (dalam syahbana 2016:3) Geogebra adalah program komputer untuk membelajarkan matematika khususnya geometri dan aljabar. Beberapa manfaat program Geogebra dalam pembelajaran matematika sebagai berikut: a) membuat sautu gambar geometri dengan teliti dan tepat, b) dapat sebagai bahan untuk mengujikan hasil gambat geometri yang sebenarnya, c) membantu juga dalam melihat sifat-sifat gambar tersebut. Selain dari manfaat tersebut geogebra dapat memvisualisasikan bentuk-bentuk geometri sehingga akan mambantu meningkatkan pemahaman konsep geometri, seperti kubus,balok, prisma, dan limas menggunakan grafik tiga dimensi. Berdasarkan keunggulan yang dimiliki software tersebut, diharapkan geogebra merupakan software yang tepat untuk digunakan dalam pembelajaran dan permasalahanpermasalahan yang dihadapi dalam pembelajaran matematika khususnya materi bangun ruang pada kelas VIII. Berdasarkan permasalahan tersebut, penerapan penggunaan software geogebra untuk sangat cocok digunakan dalam pembelajaran matematika pada materi kubus dan balok kelas VIII. Oleh karena itu perlu dilakukan penelitian dengan judul Penggunaan Software Geogebra untuk Meningkatkan Kemampuan Komunikasi Matematis dan Keaktivan Siswa Kelas VIII SMP Dharma Wanita Pertiwi Pada materi Kubus dan Balok.

\section{METODE}

Metode penelitian yang digunakan yaitu penelitian tindakan kelas. Menurut Tampubolon (2014: 19) menyatakan bahwa penelitian tindakan kelas adalah penelitian yang dilaksanakan oleh pendidik/calon guru di ruangan kelasnya sendiri secara kolaboratif/partisipatif untuk memperbaiki kinerja pendidik menyangkut kualitas proses pembelajaran, dan meningkatkan hasil belajar peserta didik menyangkut kualitas proses pembelajaran, dan meningkatkan hasil belajar peserta didik, baik dari aspek akademik maupun nonakademik, melalui tindakan reflektif dalam bentuk siklus. Dapat disimpulkan bahwa Penelitian Tindakan Kelas adalah penelitian yang dilakukan oleh pendidik atau calon pendidik dalam proses pembelajaran di dalam kelas yang dapat meningkatkan hasil belajar siswa.

Cartesius: Jurnal Pendidikan Matematika Vol. 3, No. 1

CProdi Pendidikan Matematika Universitas Katolik Santo Thomas 
Pada penelitian tindakan kelas ini diharapkan dapat meningkatkan kualitas siswa baik dalam aspek pemahaman, maupun aspek-aspek lain yang bermanfaat bagi siswa untuk menjadi dewasa seutuhnya. Adapun prosedur penelitian tindakan kelas dengan model Kemmis dan McTaggart yang terdiri dari perencanaan tindakan (planning), pelaksanaan tindakan (acting), observasi (observing), dan refleksi (reflecting) Saur (2013 : 27). Dalam penelitian ini menggunakan penelitian kolaboratif yaitu guru bersama peneliti berkolaborasi dalam melakukan penelitian tindakan kelas ini.

Subjek pada penelitian ini yaitu siswa kelas VIII SMP Dharma Wanita Pertiwi tahun ajaran 2018/2019 yang terdiri dari 30 siswa yaitu 16 perempuan dan 14 laki-laki. Objek penelitian ini adalah materi pelajaran kubus dan balok.

Teknik pengumpulan data yang digunakan calon peneliti pada penelitian ini adalah tes dan non-tes. Teknik tes dalam penelitian ini menggunakan tes awal dan tes kemampuan komunikasi matematis pada setiap siklus. Soal tes berbentuk uraian sebanyak 4 soal disusun sesuai indikator kemampuan komunikasi matematis. Selanjutnya, teknik non-tes yang dimaksud pada penelitian ini menggunakan lembar observasi aktivitas guru dan angket keaktivan siswa.

\section{HASIL DAN PEMBAHASAN}

Hasil tes siswa pada tes awal, siklus I dan tes siklus II setiap tes diberikan 4 soal uraian, pada setiap soal terdapat indikator kemampuan komunikasi matematis siswa. Secara keseluruhan hasil perolehan nilai rata - rata siswa pada tes awal, siklus I, tes siklus II dapat pada tabel berikut:

Tabel 1. Tingkat Kemampuan Komunikasi Matematis Siswa

\begin{tabular}{lccc}
\hline \multicolumn{1}{c}{ Kategori } & Tes Awal & Tes Siklus I & Tes Siklus II \\
\hline Nilai Terendah & 25 & 37,5 & 62,5 \\
\hline Nilai Tertinggi & 81,25 & 100 & 100 \\
\hline Jumlah Siswa yang Tuntas & 9 Siswa & 17 Siswa & 25 Siswa \\
\hline Jumlah Siswa yang Tidak & 21 Siswa & 13 siswa & 5 Siswa \\
Tuntas & 48,95 & 66,87 & 82,5 \\
\hline Rata-rata & $30 \%$ & $56,67 \%$ & $83,33 \%$ \\
Ketuntasan Klasikal & & \\
\hline
\end{tabular}

Cartesius: Jurnal Pendidikan Matematika Vol. 3, No. 1

CProdi Pendidikan Matematika Universitas Katolik Santo Thomas 
Dari tabel 1. dapat dilihat bahwa terjadi peningkatan yang diperoleh siswa dari tes awal, tes siklus I sampai tes siklus II. Pada nilai terendah siswa dan nilai tertinggi siswa adanya peningkatan dimana nilai terendah siswa juga terjadi peningkatan pada tes awal 25, siklus I bernilai 37,5 dan siklus II menjadi 62,5. nilai tertinggi juga meningkat pada tes awal 81,25, siklus I 100 dan siklus II 100. Jumlah siswa yang tuntas juga adanya peningkatan pada tes awal, siklus I dan siklus II yaitu mulai dari 9 orang siswa menjadi 17 orang siswa dari 17 orang menjadi 25 orang siswa. Pada siswa yang tidak tuntas terjadi penurunan dari tes awal, siklus I sampai siklus II. Ketuntasan klasikal juga adanya peningkatan tes awal 30\%, disiklus I 56,67\% menjadi $83,33 \%$.

Dalam setiap siklus dilakukan observasi atau pengamatan kepada guru selama proses pembelajaran berlangsung. Pengamatan dilakukan oleh guru bidang studi matematika juga disebut sebagai pengamat atau observer pada penelitian. Observer memberikan penilaian kepada peneliti yang bertindak sebagai guru dengan mengisi lembar observasi aktivitas guru. Pada setiap siklus dilakukan observasi aktivitas guru sesuai dengan pertemuan pada masing-masing siklus. Berikut tabel perbandingan hasil persentase observasi aktivitas guru pada siklus I dan siklus II:

Tabel 2. Observasi Aktivitas Guru pada Siklus I dan Siklus II

\begin{tabular}{lcccc}
\hline \multirow{2}{*}{ Pertemuan } & \multicolumn{2}{c}{ Siklus I } & \multicolumn{2}{c}{ Siklus II } \\
\cline { 2 - 3 } & Presentase & Kriteria & Presentase & Kriteria \\
\hline Pertama & $66 \%$ & Baik & $90 \%$ & Baik Sekali \\
\hline Kedua & $84 \%$ & Baik & & \multirow{2}{*}{$\begin{array}{l}\text { B0\% } \\
\text { Rata-rata } \\
\text { Nilai }\end{array}$} \\
\hline
\end{tabular}

Dari tabel 2. dapat dilihat bahwa adanya peningkatan pada observasi aktivitas guru dalam siklus I dan siklus II. Pada siklus I rata-rata nilai observasi aktivitas guru yaitu $75 \%$ dengan kriteria baik selanjutnya pada siklus II terjadi peningkatan menjadi 90\% dengan kriteria baik sekali.

Cartesius: Jurnal Pendidikan Matematika Vol. 3, No. 1

CProdi Pendidikan Matematika Universitas Katolik Santo Thomas 


\section{KESIMPULAN}

Berdasarkan hasil analisis data dan hasil penelitian, diambil kesimpulan yang berkaitan dengan model pembelajaran Think Pair Share (TPS) berbantuan software geogebra dapat meningkatkan kemampuan komunikasi matematis, dapat dilihat dari: Penerapan model pembelajaran Think Pair Share (TPS) dapat dilihat setelah pembelajaran dilakukan pada siklus I dan siklus II.

a. Sebelum pembelajaran dilakukan, diperoleh analisis data menunjukkan tingkat kemampuan komunikasi matematis siswa dengan persentase ketuntasan klasikal 30\%.

b. Setelah dilakukan tindakan dengan penerapan model pembelajaran Think Pair Share (TPS) pada siklus I dan siklus II hasil analisis data kemampuan berpikir kritis matematis yaitu $56,67 \%$ dan $83,33 \%$.

c. Pelaksanaan pembelajaran model pembelajaran Think Pair Share (TPS) berbantuan software geogebra untuk meningkatkan kemampuan komunikasi matematis siswa pada materi kubus dan balok sudah termasuk baik. Hal ini dapat dilihat dari hasil obeservasi guru dan hasil LAS.

Dari hasil data yang diperoleh, dapat disimpulkan bahwa dengan menggunakan model pembelajaran Think Pair Share (TPS) berbantuan software geogebra untuk meningkatkan kemampuan komunikasi matematis siswa pada materi kubus dan balok di kelas VIII SMP dapat diterapkan Dharma Wanita Pertiwi dengan baik.

Pelaksanaan peneilitan tindakan kelas dan hasil penelitian yang telah diperoleh oleh peneliti, dapat ditemukan saran sebagai berikut:

1. Bagi siswa, Siswa harus terlibat aktif dalam belajar dan memperhatikan instruksi guru dengan baik.

2. Bagi Guru

a. hendaknya dapat menguasai penggunaan software matematika yang berhubungan dengan pembelajaran matematika sehingga pembelajaran menjadi bervariasi, agar minat belajar siswa bertambah.

Cartesius: Jurnal Pendidikan Matematika Vol. 3, No. 1

CProdi Pendidikan Matematika Universitas Katolik Santo Thomas 
b. Penggunaan software matematika harus semakin ditingkatkan agar dapat menciptakan suasana yang baru dalam pembelajaran sehingga siswa dapat termotivasi dengan baik dan proses belajar mengajar yang menyenangkan.

Sekolah harusnya memberikan dorongan mengenai perkembangan teknologi guna untuk meningkatkan kemampuan komunikasi matematis siswa. Salah satu media yang dapat digunakan adalah software yang membantu pembelajaran matematika. Seperti halnya software geogebra yang dipadukan dengan model pembelajaran Think Pair Share (TPS).

\section{UCAPAN TERIMAKASIH}

Penulis menyampaikan terimakasih kepada Ibu Tetty Natalia Sipayung, S.Si., M.Pd. sebagai Dosen Pembimbing 1 dan Bapak Johannes Pangihutan, S.Pd., M.Si. sebagai Dosen Pembimbing 2 yang telah mengarahkan dan membimbing penulis mulai dari awal penelitian hingga berakhirnya penelitian sehingga penulis dapat menuliskan artikel ini yang merupakan bagian dari hasil penelitian penulis. Penulis juga menyampaikan terimakasih kepada Ketua Program Studi Pendidikan Matematika, Dekan, dan Rektor Universitas Katolik Santo Thomas atas dukungan yang diberikan kepada penulis.

\section{DAFTAR PUSTAKA}

[1] Akbar, Mukalladin Ulil. 2016. Penerapan Model Pembelajaran Kooperatif Tipe Think Pair Share untuk Melatih Sikap Sosial Siswa Kelas X5 SMAN 8 Makassar. Jurnal Chemica. 17(1).

[2] Amir, Almira. 2014. Kemampuan dan Penalaran Komunikasi Dalam Pembelajaran Matematika. Jurnal Logaritma. 2(1).

[3] Cakyamuni, putu ayu. 2016. Pengaruh Model Kooperatif Tipe Make A Match Terhadap Prestasi Belajar IPS Siswa Kelas IV SDN 1 Bali Sadhar Utara. [skripsi]. Fakultas Keguruan dan Ilmu Pendidikan. Universitas Lampung. Bandar Lampung

Cartesius: Jurnal Pendidikan Matematika Vol. 3, No. 1

CProdi Pendidikan Matematika Universitas Katolik Santo Thomas 
[4] Asnawati, Sri. 2013. Peningkatan Kemampuan Komunikasi Matematis Siswa SMP dengan Pembelajaran Kooperatif Tipe Teams-Games-Tournaments. Jurnal euclid. 3(2).

[5] Dasopang, Muhammad Darwis. 2017. Belajar dan Pembelajaran. Jurnal Kajian Ilmu-ilmu Agama. 03(2).

[6] Gunawan, Adhi. 2018. Penerapan Model Pembelajaran Think Pair Share untuk Meningkatkan Social Skill Siswa [Tesis]. Fakultas Keguruan dan Ilmu Pendidikan. Universitas Lampung. Bandar Lampung.

[6] Hasratuddin. 2014. Pembelajaran Matematika Sekarang dan yang Akan Datang Berbasis Karakter. Jurnal Didaktik Matematika. 1(2).

[7] Hati, Nursa'adah. 2017. Pengaruh Model Pembelajaran Make A Match Terhadap Kemampuan Komunikasi Matematis dan Keaktifan Siswa Pada Pembelajaran Matematika di Kelas VIII SMPN 2 Godean [Skripsi]. Fakultas Keguruan dan Ilmu Pendidikan. Univarsitas Mercu Buana Yogyakarta. Yogyakarta.

[8] Hidayah, Umy Aris Nur. 2017. Upaya Guru PAI dalam Meningkatkan Keaktifan Belajar Mapel PAI Melalui Strategi Active Knowledge Sharing Pada Siswa Kelas IV SDN 2 Denggungan Kecamatan Banyudono Kabupaten Boyolali Tahun Pelajaran 2016/2017 [Skripsi]. Fakultas Ilmu Tarbiyah dan Keguruan. Institut Agama Islam Negeri Surakarta.

[9] Izzati, Nurma. 2014. Pengaruh Keterampilan Sosial Terhadap Kemampuan Komunikasi Matematis Mahasiswa. Jurnal Edueksos. III(1).

[10] Kariani, Ribka. (2013). Pengaruh Pembelajaran Think Talk Write (TTW) Terhadap Kemampuan Komunikasi Matematik dan Sikap Positif Siswa Terhadap Matematika. [Tesis] Unimed.

[11] Kurniawan, Hana. 2012. Penerapan Metode Pembelajaran Kooperatif Teknik Think Pair Share Untuk Meningkatkan Motivasi Belajar Akuntansi Kompetensi Dasar Menghitung Mutasi Dana Kas Kecil Siswa Kelas X Akuntansi 2 SMK Negeri 7 Yogyakarta. Jurnal Pendidikan Akuntansi. Indonesia. X(1).

Cartesius: Jurnal Pendidikan Matematika Vol. 3, No. 1

CProdi Pendidikan Matematika Universitas Katolik Santo Thomas 
[12] Kurniawati, Chintya. 2017. Pengaruh Keaktifan Belajar dan Motovasi Belajar Terhadap Hasil Belajar Siswa Kelas VIII B SMP Kanisus Kalasan Pada Topik Operasi Aljabar Menggunakan Model Kooperatif Tipe Jigsaw II Tahun Ajaran 2016/2017 [Skripsi]. Fakultas Keguruan dan Ilmu Pendidikan. Universitas Sanata Dharma: Yogyakarta.

[13] Mahmudi, Ali. 2015. Keefektifan Experiential Learning Pembelajaran Matematika MTS Materi Bangun Ruang Sisi Datar. Jurnal Riset Pendidikan Matematika. 2(2).

[14] Maulani, Dewi. 2017. Pengaruh Penerapan Model Recipropocal Teaching Terhadap Kemampuan Komunikasi Matematis Ditinjau Dari Self-Concept Siswa di SMAN Kecamatan Tambun Selatan Bekasi. JPPM. 10(2).

[15] Mulyastuti, Indah Dwi. 2017. Pengembangan Media Pembelajaran Matematika Berbasis Geogebra Pada Materi Garis Singgung Lingkaran Untuk Siswa Kelas VIII SMPN 1 Purwodadi [Skripsi]. Fakultas Keguruan dan Ilmu Pendidikan. Univarsitas Muhamadiyah Surakarta.

[16] Ningrum, Dian Ayu Setia. 2016. Keaktifan dan Kemampuan Komunikasi Matematis Siswa Pada Pembelajaran Kooperatif Tipe Tsts Berbantuan LKS Materi PLDV Kelas VIII [Skripsi]. Fakultas Matematika dan Ilmu Pengetahuan Alam. Universitas Negeri Semarang: Semarang.

[17] Ningsih, Ica 2105. Efektivitas Model Pembelajaran Kooperatif Tipe Question Students Have (Qsh) Terhadap Hasil Belajar IPA Siswa Kelas VII SMP Negeri 11 Yogyakarta. Jurnal Pendidikan IPA. 2(1).

[18] Nopiyani, Dian. 2016. Penerapan Pembelajaran Matematika Realistik Berbantuan Geogebra Untuk Meningkatkan Kemampuan Komunikasi Matematis Siswa SMP. Jurnal Mosharafa. 5(2).

[19] Rusman. 2017. Belajar dan Pembelajaran. Jakarta. PT Kharisma Putra Utama.

[20] Skolikhah, Ria Amalia. 2014. Meningkatkan Keaktifan dan Hasil Belajar Siswa Pada Mata Pelajaran IPA Melalui Penerapan Metode Eksperimen Kelas V SDN 1 Sedayu Tahun Ajaran 2013/2014 [Skripsi]. Fakultas Keguruan dan Ilmu Pendidikan. Universitas Negeri Yogyakarta: Yogyakarta.

Cartesius: Jurnal Pendidikan Matematika Vol. 3, No. 1

CProdi Pendidikan Matematika Universitas Katolik Santo Thomas 
[20] Sholilah, Ummu. 2018. Kemampuan Komunikasi Matematis Siswa dalam Menyelesaikan Soal Materi Komposisi Fungsi Ditinjau dari Kemampuan Matematika. Jurnal Tadris Matematika. 1(1).

[21] Siagian, Muhammad Daut. 2016. Kemampuan Koneksi Matematika dalam Pembelajaran Matematika. Journal of Mathematics Education and Science. 2(1).

[22] Suharmini, Arikunto. 2010. Prosedur Penelitian. Jakarta. Rineka Cipta.

[23] Suharmin, Arikunto. 2010. Manajemen Penelitian. Jakarta. Rineka Cipta.

[24] Titisari, Fransisca Niken. 2017. Efektivitas Penggunaan Program Geogebra Pada Pembelajaran Matematika Materi Geometri Terhadap Motivasi dan Hasil Belajar di Kelas X SMA Bopkri 2 Yogyakarta Tahun Ajaran 2016/2017 [Skripsi]. Fakultas Keguruan dan Ilmu Pendidikan. Universitas Sanata Dharma. Yogyakarta.

[25] Wijayanti, Noviana. 2014. Penerapan Model Pembelajaran Kooperatif Tipe Think Pair Share Untuk Meningkatkan Hasil Belajar Matematika Siswa Kelas IV SDN 01 Ampel Kecamatan Ampel Boyolali Semester Genap Tahun Ajaran 2013/2014 [Skripsi]. Fakultas Keguruan dan Ilmu Pendidikan. Universitas Kristen Satya Wacana: Salatiga.

Cartesius: Jurnal Pendidikan Matematika Vol. 3, No. 1

CProdi Pendidikan Matematika Universitas Katolik Santo Thomas 